\title{
Developing English Learning Materials Based on Students' Needs for Hotel Management Study Program Students at Universitas Negeri Padang
}

\author{
Elismawati and Mukhaiyar \\ UIN Imam Bonjol Padang \\ elismawati_1957@yahoo.com
}

\begin{abstract}
The development of the global tourism industry rapidly, make the importance of English ability for specific fields of work, including hotel management. For preparing the graduates, Hotel Management Study Program UNP provides English Profession 1, 2, and 3 subject. Unfortunately, implementation does not give significant contribution in improving graduates' English ability. Its learning materials do not fulfill the students' needs, so that learning materials development was carried out through research and development. The research used ADDIE model that stands for the phases of Analyze, Design, Develop, Implement, and Evaluation. The data was obtained through conducting interview and spreading questionnaires to students, lecturers, head department, three hotels' managers, alumni, and experts. Need analysis found English skill, teaching methodology, new topics and language focus which are appropriate for the students. The content was designed and developed based on the students needs. This developed learning material has been assessed as valid and recommended by experts through validation judgment. Then it was found that the developed learning materials were categorized 'practical' to be used by students Hotel Management Study Program UNP
\end{abstract}

Keywords—English for Hotel Management Study Program UNP, learning Material, Learning Material development, Needs Analysis

\section{INTRODUCTION}

Indonesia has done many attempts to attract international tourist such as promotions and campaigns to come to Indonesia because the tourism industry is one of main economic attractions. Due to the results, the number of international tourists continuously increased every year. It is undeniable that tourism plays an important role in solving some problems, especially the problem of unemployment in Indonesia. The tourism will create some jobs for people and increase income for the country.

Universitas Negeri Padang is as one of the outstanding universities in West Sumatera, tries to contribute to the development of Indonesian tourism with its Hotel Management Study Program (henceforth, HMSP) as part of the Faculty of Tourism and Hospitality. This program established in 2009 with the vision to be centre of excellence in the national level which produces competence, religious, nationality-oriented, and open-minded professionals in the Hotel Management Program without forgetting the scientific pillars. The vision is supported by the missions 1) have belief, piety, kindness personality, and nation-oriented in their professionalism 2) have abilities in undertaking duty which based on capability, creativity, dedication, truthfulness, discipline, wisdom, and able to communicate both spoken and written language 3) have abilities in manage the hotel accommodation based on national and international standard (Documentation of Home Economics Department; 2014).

Based on the missions the HMSP students have to able to communicate both spoken and written language, they are not only prepared by the professional knowledge but also the communicative English competence that can be used in their future job. The English subject taught to Hotel Management Study Program students labelled as English for Profession 1, 2 and 3. The English for Profession 1 taught in the first semester, English for Profession 2 in the second semester, and English for Profession 3 in the sixth semester.

Moreover, based on the Framework of Indonesian National Qualification (Kerangka Kualifikasi Nasional Indonesia, KKNI: 2009) the D IV Hotel Management Study Program students are on the sixth level. The level of Vocational Education that the students are expected to have English abilities such as 1) be able to communicate in English for Tourism 2) be able to organize the English for Tourism communication professionally, 3) be able to apply the different communication stages in every occasion and 4) be able to be a problem solver in the duty using English for Tourism communication.

The Hotel Management Study Program students should be able to compare and integrate between Education fields, work-training field also work experience. Thus, definitely, they need English based on their occupation. The English that is derives from Hutchinson \& Waters (2008: 21) simple question: "Why does the learner need to learn a foreign language?"

Based on the interview and observation were done by the writer at Hotel Management Study Program Universitas Negeri Padang that English class faced some problems especially those related to the course design, the students, and the learning 
materials. The course is designed independently by the lecturers. The university required the students to be able to use oral and written English in professional context, but such restriction is too broad to be defined by the lecturer as the course designer. For this reason, the writer carried out a study concerning on developing English learning materials based on the students' need as an alternative solution. Considering the phenomenon explained above, the present study is aimed to answer the following research questions: 1) What are the needs of HMSP Students at Universitas Negeri Padang? 2) How is learning materials developed? 3). How valid are the developed learning materials? 4). How practical are the developed learning materials?

\section{English for Specific Purpose (ESP)}

ESP is defined as an approach to language teaching in which all decisions as to content and method are based on the learner's reason for learning (Hutchinson and Waters, 1987:19). ESP has a long history in the field of language teaching, in which it was started in the 1960s when general English course could not meet the needs of language learners. There are three common to the emergence of ESP courses: the demands of Brave New World, a revolution in linguistics and focus on the learner (Hutchinson and Waters, 1987:23).

\section{Learning Material Development in ESP}

Learning material development as an aspect in teaching English for Specific Purposes has purpose to analyze the students ${ }^{\star}$ need and conduct teaching material in order to get synchronize between students ${ }^{6}$ need and teaching material itself. Byram (2000:286) argues that teaching material development is a process to find out of student's need and to tailor of design material to fit those needs. It means that teaching material development in English for Specific Purposes not only focus on providing material but also analysis of student's need. Hence, the material which is given will fix and support students to reach their needs in workplace.

\section{Need Analysis.}

Needs analysis has a vital role in the process of designing and carrying out any language courses (Hutchinson and Waters, 1987:53). Similarly, Dudley- Evans and St John (1998:121) put NA at the first stage before conducting other stages such as course and syllabus design, materials selection (and production), teaching and learning, and evaluation in the process of designing ESP course.works related to designing language instruction including, in this case, developing learning materials.

\section{METHOD}

The type of this research is research and development ( $R$ and $D)$. This research is focused to develop English learning materials based on content-based instruction approach with respondent divided into two groups. The respondents of this research were 112 students of the second year, 2 lecturers, head department, three hotels' managers, alumni, and experts.

As this study applied research and development method referring to the ADDIE model analyze, design, develop, implement, and evaluation, the data were analyzed in four phases, excluding evaluation, from various instruments for different respondents. The analysis was based on descriptive statistics such as frequency, percentage, and means. In analysis phase frequency and percentage were calculated to find out the student's needs from a set of questionnaire that covers the aspects of target situation analysis and objective needs; wants, means, subjective needs analysis; present situation analysis; lack analysis; learning needs analysis; linguistics analysis; what is wanted from the course; and means analysis. The highest percentage of the student's responses toward that analysis was the first priority to be considered in designing phase. Before distributing the instrument to 112 the second year students, it was validated by hospitality expert.

The data of designing and developing phases were analyzed from an instrument called validation checklists to find out the validity of the product. There were three validation checklists to be completed by 1 hospitality expert and 2 experts of materials developments and language uses. Those experts evaluated the design and the developed materials by scoring the content, language understanding, presentation, and writing mechanics. The scoring system referred to the rubrics of materials development developed from The Guide of Materials Development issued by the Department of National Education in 2008. The classification of the validity of the product was in accordance with Riduwan's category (2005:89).

In implementation phase, another descriptive statistics such as finding means, percentage and average score were calculated to summarize the practicality of the product. The calculations were obtained from responses that were classified to afour point scale (1) impractical, (2) less practical, (3) practical, (4) very practical. Two sets of questionnaire were used as the instruments. The first one was distributed to 12 classes of the second year students. It was to evaluate the students ' perceptions in terms of the compliance of time, the conveniencelease of using content-based English learning materials for HMSP students, and the benefits of using content-based English learning materials for the HMSP students. Another set of the instrument was given to 2 lectureres who are professional in hospitality and 2 English lecturers background. It was to find out the lecturers' perception related to the compliance of time, the conveniencelease of using content-based English learning materials for HMSP students, and the completeness of the components of content-based learning materials for HMSP students. 
The average scores from two groups of 112 students and 2 lecturers were calculated separately to find out the final score of product practicality from each group. Data drawn in each phase were interpreted and discussed. The results in analysis phase were obtained from the analysis of 8 aspects. The first one was personal information about learners and their attitudes towards English. It was found that $72.57 \%$ of the students realize that English is very important. More specifically, they agreed that it is important not only for academic but also for professional needs. Therefore, $70.11 \%$ of the students preferred learning English for Hotel Management Purposes to General English. However, $73.26 \%$ of the students seldom make extra efforts to improve their English. Consequently, the second aspect, lacks analysis informed that their masteries of English proficiency and English for Hotel Management Purposes were mostly categorized in poor level.

In addition, the third aspect, language information about target situation informed that such conditions were caused by the absence of needs analysis before class and learning materials containing business topics. For that reason, they could not improve their ability in using English for both academic and working purposes in Hotel Management field. The fourth aspect of analysis was related to the situation where English is mostly used Hotel Management It was found that the highest percentage was in the situation of Greetingand ReceivingGuests $79.29 \%$, followed by the situations of Responding the guest Needs by Hall porter each of which gets a portion of $78.12 \%$, Responding Guest Hotel and Restaurant- Payments 74.67\%, Responding to the Hotel guest leaving $70.13 \%$, and Directing Guest by Hall porter and Chambermaid $67.11 \%$. The rest situations such as OfferingHelpandAdvice, AskingForandGivingOpinions, GivingInstructions, DescribingFunctionsandPurposes, and Shoppingatthe Hotel ranked the lowest that are all less than $32 \%$.

The fifth aspect was related to language learning needs that cover the aspect of language skills and learning activities that the students need most. It was found that $84.78 \%$ of the students need speaking skill and followed by listening $80.45 \%$, reading $79.54 \%$, and writing $50.56 \%$. Learning activities that they wanted most to do was pair work' $81.00 \%$. Another aspect was an analysis related to the business topics the students want most to learn. It shows that the students were interested in five topics that were ranged from $82.43 \%$ to $73.11 \%$. It was found that the students need to improve their ability in using English for business for both academic and working purposes $91.14 \%$. The last aspect was means analysis. It was informed that the students wanted to learn English using business contents materials from the second year at the $2^{\text {nd }}$ semester $67.43 \%$ and wanted to be taught by a team that consists of specific business and English educational background lecturers.

Following the analysis phase, it was essential to outline a diagram as a guide in the designing phase. It can be seen in the following figure. The design of the developed materials is drawn in the following diagram.

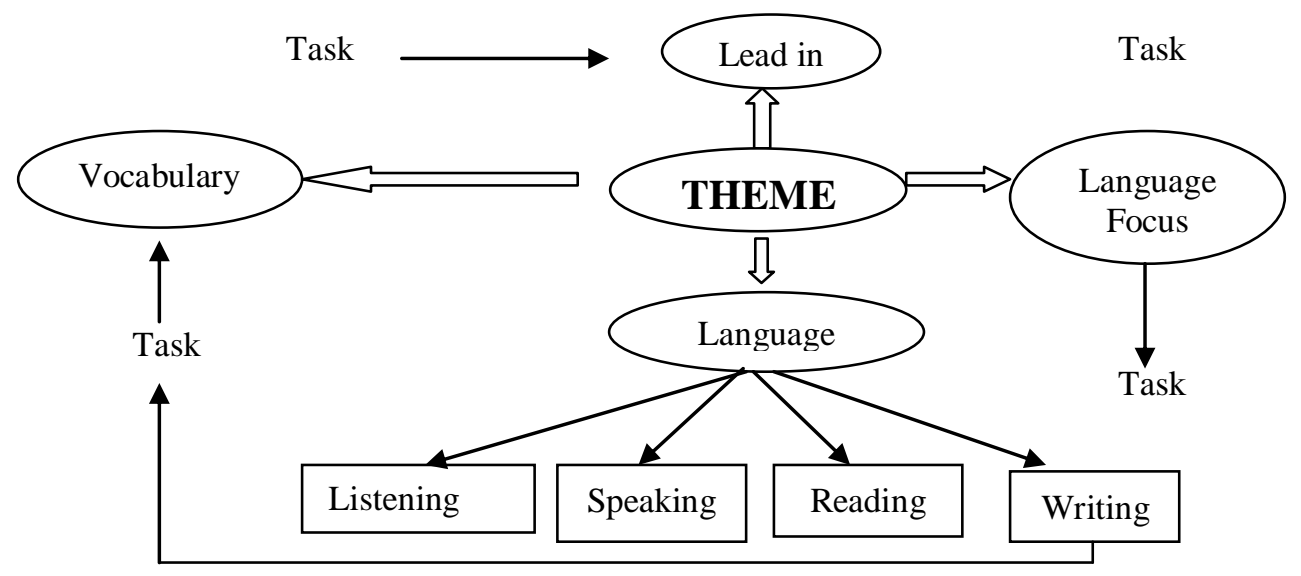

Fig. 1. The design of the developed materials

The diagram briefly shows how the designing process was initiated from the development of main themes that the students wanted to learn most. The themes were the data taken from the previous phase. From the themes/main topics, 9 subtopics were developed in accordance with the number of handouts used for one semester, 14 meetings excluding mid-term and final tests. The themes also became the starting points to decide the organization and the contents of the developed materials. The organization consisted of four main parts. They were lead in, vocabulary, language focus, and language skills. Then, the language skills were divided into four parts that cover listening, speaking, writing, and reading skills. To complete the contents and tasks of ach part, the activities of selecting appropriate syllabus, determining learning objectives, choosing topics and sub topics, collecting and choosing appropriate texts, deciding learning sources, and designing tasks were documented as a blueprint of the developed materials.

The blueprint was validated by the expert of material development who recommended some suggestions. First, it was suggested to draw a chart to outline the organization of the materials. Second, it was suggested to include examples in professional context in language focus section. After designing phase, the writer developed the blueprint to be real printed 
materials in a handout model. To get a better result and a valid product, it was validated by the experts of business content and materials development that cover the aspects of contents, language understanding, presentation, and writing mechanics.

Based on the expert's evaluation validation, the developed materials were rated in the category of valid. However, they suggested revising some elements. Validator 1 recommended revising the front page of each handout. She also suggested revising the level of difficulty of task in handout 2. So, the task had been revised from writing a short paragraph to rearrang jumbled words to be a complete sentence. Validator 2 advised to give clear explanation in order to avoid student's misunderstanding that they don't know what to do first. Validator 3 revised the materials in terms of professional context and their sequences. He suggested including the discussion about professional context.

Based on the validator's suggestions, the writer revised and printed the materials to be a product that can be applied in a try-out session in implementation phase. After the tryout session,the writer found that the lecturers and the students agreed that the developed materials were practical for HMSP students. However, the indicator of the compliance of time was rated the lowest score. The highest score was obtained from the indicator of how benefits the materials are. It scored 90.94 and was categorized very practical.

\section{FINDING AND DISCUSSION}

In this part the writer discusses the 4 phases of research procedure which are also to be the answers to the research questions defined in chapter 1 .

\section{Analysis}

Before designing learning materials used for a learning process, conducting Need Analysis is undeniable. Hutchinson and Waters, (1987:52) clearly points out that needs analysis has a vital role in the process of designing and carrying out any language courses. Besides, defining the students ${ }^{\text {ee }}$ needs is the way to find out the reasons for which the students are learning English (Dudley- Evans and St John, 1998:121). The data of analysis phase informs that the students in HMSP Universitas Negeri Padang needed English for Hotel Management Purposes which enables them to master hospitality subject as well as to prepare them to use Professional English for working purposes. However, the data of lack analysis showed that their masteries on English for Professional Purposes were categorized in „poor" level. Therefore, they prefer learning English related to the business topics.

To help them in the process of learning English for the professional purposes, the students mostly preferred to do ,pair work $^{e e}$ for their classroom activities. In addition, the analysis also showed that the students want to study English for professional purposes are taught by a team that consists of professional and English language educational background lecturers.

\section{Designing}

Based on the result of needs analysis in the first phase, the writer continued to the second phase called design. This phase was the activity that inspires the writer to find the answer to the second research question - How is the content-based learning material for the HMSP students designed? Therefore, in this phase the writer decided to design a course syllabus on the basis of information gathered in the analysis phase. Since the analysis showed that the students prefer learning English for professional purposes to English for general purposes, the writer decided to pick content-based syllabus as a guide to develop the teaching materials. It is based on the premise declared by Richards (2001:157). He claims that „with topical syllabus, content rather than grammar, functions, or situations is the starting point in syllabus design ${ }^{\text {ee }}$ Therefore, the writer listed the professional topics in the questionnaire, in the syllabus and materials design based on the business language tasks and skills defined in the curriculum of business reported by Hussin (in Orr, 2002:37-39). The language tasks and skills mentioned in the curriculum are explained in detail in chapter 2.Based on the analysis of language learning needs and lacks analysis, it was found that the students' weaknesses were in speaking skill. Therefore, they need speaking more than other. Thus, the writer design more tasks in speaking section. The tasks were not only practicing questions and answers but also performing role plays in business contexts related to topic discussion.

\section{Developing}

After designing phase, the writer developed the learning materials that then followed by a validation process. The validation result shows that the learning materials developed based on the content-based approach for students of HMSP Universitas Negeri Padang were categorized "very valid". It was quite reasonable for the reasons that the writer had followed a procedure of developing learning materials adapted from Nunan's procedure (1991:216). In the procedure, he outlines some activities such as selecting topics; collecting data; determining what learners will need to do in relation to texts; creating pedagogical activities/procedures; analyzing texts and activities to determine the language elements; creating activities focusing on language elements; creating activities focusing on learning skills/strategies, and creating application tasks. 


\section{Implementation}

After the completion of the developed materials in a handout model, the writer came to a try-out session to see the feasibility of the developed materials in an activity called implementation phase. The result of the implementation phase showed that in general, the students " perception on the practicality of the developed materials was categorized „practical". However, the indicator of the compliance of time obtained the lowest score. It was categorized "fairly practicale . The writer assumed that such result was due to the subject matters discussed in each handout were too much. Besides, the students found that the tasks were much more difficult for the reason that it was their first time to use learning materials specifically related to hospitality..

The highest score that reached ,very practical“ category was the indicator related to the benefits of using contentbased English learning materials for the HMSP students. It means that learning materials that contain topics developed from professional context are very helpful to support their mastery on business for both academic and working purposes.

In line with the students ${ }^{\text {ee }}$ perception, both of the lecturers also rated the „compliance of time ${ }^{\text {ee }}$ into „fairly practical ${ }^{\text {ee }}$ category for the same reason. But, the indicator related to the completeness of the components of content-based teaching materials for HMSP students achieved the highest category - ,very practical ${ }^{\text {ee }}$. It was quite reasonable because the product covers the 4 languages skills and is equipped with language focus and vocabulary sections that each of which is followed by a task.

\section{CONCLUSION AND RECOMMENDATION}

This is a research and development study that aims to develop English learning materials based on students 'need. More specifically, the primary purposes of the study are to find out the real needs of the HMSP students, to design and to develop learning materials, and to find out the validity and practicality of the developed materials. As a result, the final products of this study are a set of content-based syllabus and a content-based handout. The findings in analysis phase informed that the real needs of the HMSP students. They preferred learning English for Professional Purposes to General English. The findings in designing and developing phases showed that the product was categorized very valid. Results in implementation phase proved that the products were practical to be used HMSP Universitas Negeri Padang. However, the writer realizes that there are some weaknesses found in the final product for the limitation of the research. Based on the discussion and conclusion, it is suggested several things as follows: The English language program in HMSP will be better if it is designed by both the hospitality experts and the English language experts to avoid the difference between English content and the use in the hotel industry.

\section{References}

Astika, G. 2012. Teacher and child talk in 'paud' English class. In M. Syafe'i, H. Madjdi, \& Mutohar (Eds.), Proceedings of the $2^{\text {nd }}$ National Conference on Teaching English for Young Learners in Indonesia (pp. 46-57). Kudus, Indonesia: Muria Kudus University

Brown, H.D., (2007). Teaching by Principles: An Interactive Approach to Language Pedagogy, the $2^{\text {nd }}$ Edition. New York: Longman

Chen, Y (2015). Content-based Business English Course for EFL. The Internet TESL Journal. iteslj.org/.../ChienBusinessEnglish. Html

Crystal, D. 2003. The cambridge encyclopedia of the English language (2nd ed.). Cambridge: Cambridge University Press.

Davies, S. (2003). Content Based Instruction in EFL Context. The Internet TESL Journal, Vol. IX, No.2. http://iteslj.org/

Dudley-Evans, T. \& Jo St John, M. (1998). Developments in English for Specific Purpose: A multi-disciplinary approach. Cambridge: Cambridge University Press

Hutchinson, T., \& Waters, A. 1987. English for specific purposes: A learningcentred approach. Cambridge: Cambridge University Press

Mario Cal, Varela. 2010. Current Issues in English Language Teaching and Learning. Cambridge: Cambridge University Press

Francisco Javier Fernández Polo, Lidia Gómez García and Ignacio M. Palacios Martínez This book first published 2010 Cambridge Scholars ...

Michael,Byram.2000. Teaching Material Development. Cambridge: Cambridge University Press

Ministry of Education of the Republic of Indonesia (e.g. the decree No. 060/ U/ 1993, No. 020/ U/ 2003, \& No.12/ U/ 2012).

Nunan, D. (1991). Language Teaching Methodology. Cambridge: Cambridge University Press

Orr, T. (2002). English for Specific Purposes. Case Studies in TESOL Practice Series, Jill Burton, Series Editor. Virginia: Teachers of English to Speakers of Other Languages, Inc.

Richards, J.C. (2001). Curriculum Development in Language Teaching. Cambridge: Cambridge University Press. Richards, J.C. (2005). Communicative Language Teaching Today. RELC Portfolio Series 13. Singapore: SEAMEO Regional Language Center.

(2001). Approaches and Methods in Language Teaching. Second edition. Cambridge: Cambridge University Press

Riduwan. (2005). Belajar Mudah Penelitian Guru, Karyawan, dan Peneliti Muda.Bandung: Alfabeta 
Ur, Penny (1991) A Course in Language Teaching: Practice and Theory Cambridge: Cambridge University Press. Villalobos, O. B. (2013). Content-Based instruction: A Relevant Approach of

Language Teaching. Journal of Innovation Education. Vol. XV. No. 20. 